Article

\title{
Occurrence of Ochratoxin A in Southern Spanish Generous Wines under the Denomination of Origin "Jerez-Xérès-Sherry and 'Manzanilla' Sanlúcar de Barrameda"
}

\author{
$M^{a}$ Teresa Murillo-Arbizu ${ }^{1}$, Susana Amézqueta ${ }^{2}$, Elena González-Peñas ${ }^{2, *}$ \\ and Adela López de Cerain ${ }^{1}$
}

1 Department of Nutrition, Food Science, Physiology and Toxicology, School of Pharmacy, University of Navarra, 31008, Pamplona, Spain; E-Mails: mmurarb@alumni.unav.es (M.M.-A.); acerain@unav.es (A.L.C.)

2 Department of Organic and Pharmaceutical Chemistry, School of Pharmacy, University of Navarra, 31008 Pamplona, Spain; E-Mail: samezqu@alumni.unav.es (S.A.)

* Author to whom correspondence should be addressed; E-Mail: mgpenas@unav.es.

Received: 25 March 2010; in revised form: 14 April 2010 / Accepted: 11 May 2010 /

Published: 12 May 2010

\begin{abstract}
The mycotoxin ochratoxin A (OTA) has toxic effects in animals; the most relevant of them is nephrotoxicity. OTA has also been classified as a possible carcinogen for humans (group 2B) by the International Agency for Research on Cancer (IARC). Therefore, exposure to OTA through contaminated food can represent health impairment to humans. The maximum permitted level for this mycotoxin in wine is $2.0 \mu \mathrm{g} / \mathrm{L}$. The presence of OTA in Spanish wines produced using the traditional methods under the Denomination of Origin "Jerez-Xérès-Sherry and manzanilla Sanlúcar de Barrameda" was evaluated by a High performance Liquid Chromatography method with fluorescence detection and immunoaffinity column purification. A recovery of $95.4 \%$ and a limit of detection and quantification of $0.009 \mu \mathrm{g} / \mathrm{L}$ and $0.02 \mu \mathrm{g} / \mathrm{L}$ respectively, were achieved. In manzanilla, fino, amontillado and oloroso wine, the mean OTA values were $0.042,0.044,0.144$, and $0.319 \mu \mathrm{g} / \mathrm{L}$, respectively. These levels are not different from other data given in the reference literature on white wines, although fino and manzanilla wines have very low OTA levels.
\end{abstract}

Keywords: mycotoxins; ochratoxin A; liquid chromatography; wine; Jerez; Xérès; Sherry; manzanilla 
Abbreviations: Body weight (bw); High Performance Liquid Chromatography (LC); Immunoaffinity columns (IAC); International Agency for Research on Cancer (IARC); Limit of Detection (LOD); Limit of Quantification (LOQ); Ochratoxin A (OTA); Phosphate Buffered Saline (PBS); Provisional Tolerable Weekly Intake (PTWI)

\section{Introduction}

Ochratoxin A (OTA) is produced by filamentous fungi of the genera Aspergillus and Penicillium. The molds that produce OTA in grapes belong to Aspergillus section Nigri, with A. Carbonarius being the most important producer [1]. The growth of mold and the production of this mycotoxin are dependent on several factors such as high temperature and humidity during growth, harvesting, subsequent drying, and food storage.

OTA is a moderately stable molecule that can remain after most types of food processing and therefore, it appears in a wide variety of foodstuffs. Cereals and cereal products are the main sources of OTA intake, followed by wine, grape juice and coffee [2].

The OTA toxic effects have been studied in different animal species, with nephrotoxicity and hepatotoxicity being the most relevant; in addition, and regarding human beings, OTA has been suspected of being involved in the etiology of Balkan Endemic Nephropathy [3], and the International Agency for Research on Cancer (IARC) has classified OTA as a possible carcinogen for humans (group 2B) [4]. Therefore, exposure to OTA through consumption of contaminated food can represent a source of health impairment to humans. Human exposure has been assessed by the analysis of human plasma or serum for OTA, which has revealed the existence of a worldwide chronic exposure to low levels of OTA, including Spain [5]. For a recent review see Pfohl-Leszkowicz and Manderville 2007 [6].

In order to minimize public health risk, European countries have established OTA limits for different food matrices: cereal, coffee, wine and its derivatives. More specifically, the maximum permitted levels for wine (white wine, rosé wine and red wine) is $2.0 \mu \mathrm{g} / \mathrm{L}$ [7], which is in accordance with the proposed maximum OTA levels in wine cited in different studies [8].

Wine is a product widely consumed in both developed and developing countries. The presence of OTA in wine was reported for the first time in 1995 [9]. Due to the fact that wine is considered to be a second source (after cereals) of daily OTA intake in human beings [1,10], it is necessary to study the presence of this mycotoxin in wine. Many methods for determining the presence of OTA in this beverage and several studies regarding the presence of this mycotoxin in wine have been carried out worldwide [1,11-17]. Reference literature has indicated that there is a higher OTA concentration in red wines than in rosé or white wines [11,17]. It should be also pointed out that the further south the origin of the wine samples is in Europe, the higher the frequency of occurrence and the concentration of OTA in red wine [17,18].

The OTA levels in wine depend on different factors such as the climate, the date of harvesting and different wine-making procedures [1,5]. A special type of wines are those produced according to the traditional methods as stipulated by the controlling body of the Denomination of Origin "Jerez-XérèsSherry and manzanilla Sanlúcar de Barrameda" in a southern region of Spain, Cadiz. These wines are 
produced from white grape varieties (mainly Palomino and Pedro Ximenez) but using different ageing procedures.

During the ageing of fino and manzanilla wines there is a development of yeast of the Saccharomyces genus on the wine surface, which forms a film called, "blooming veil" or "flor veil". Manzanilla wines are only produced in Sanlúcar de Barrameda (Cadiz, Spain) where the climate conditions allow the yeast to remain alive throughout the entire year. In fino wines, the yeast disappears in summer and winter and therefore, the wine alternates biological and oxidative ageing periods. Amontillado wines are aged under similar conditions to those of fino wines, but when the yeast has disappeared ethanol is added and they are subjected to oxidative ageing. Oloroso wines are produced through exclusively oxidative ageing by increasing the ethanol content to $18-20^{\circ}$ in the starting wine in order to avoid spontaneous growth of "flor yeast".

All these types of wines are aged by following a traditional dynamic system called "Soleras" and "Criaderas" (Figure 1).

Figure 1. Dynamic System of "Criaderas" and "Soleras" wine ageing.

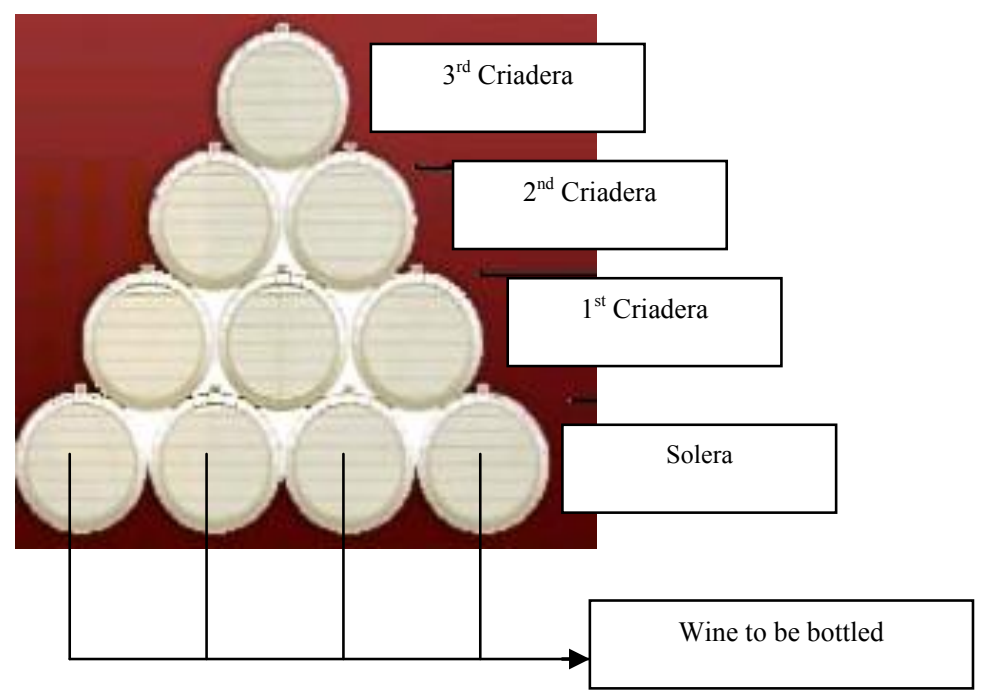

These wines are stored in American oak casks piled up in such a way as to form a pyramid, where each level is called criadera and the lowest level is called the solera. Because yeast requires nutrient renovation in order to survive, there is a periodical mixing of ageing wines with younger wines. The product to be bottled and sold is extracted from the solera level casks and after that, the solera is replenished by a younger wine from the first criadera stage. This process of substitution continues, involving all of the levels.

The aim of this study was to evaluate the presence of Ochratoxin A in Spanish generous wines (fino, manzanilla, amontillado, and oloroso) and also to study the influence that the particular ageing process of these types of wines could have on OTA contamination. The data about OTA contamination in these wines are very interesting because these wines are widely consumed in southern Spain, and large quantities of these wines are also consumed in countries such as Holland, Great Britain, Germany, and the United States, having imported them from Spain. 


\section{Material and Methods}

\subsection{Wine samples}

Forty wine samples were analyzed: fino $(\mathrm{n}=10)$, manzanilla $(\mathrm{n}=10)$, amontillado $(\mathrm{n}=10)$ and oloroso $(\mathrm{n}=10)$. Due to the particular ageing system, the bottled wine was a mixture of wines from different years. The samples were purchased from supermarkets and small specialized wine shops and analyzed during 2003. The samples were stored in their original bottles at $4-5{ }^{\circ} \mathrm{C}$ until analysis was carried out. The day before the analysis, the samples were taken out the fridge in order to temperate them.

\subsection{Chemicals and reagents}

Ochratoxin A (99.6\%) was purchased from Sigma (St. Louis, MD, USA). All of the reagents were pro-analysis grade. Sodium acetate and phosphoric acid were purchased from Panreac (Barcelona, Spain); acetonitrile and methanol LC grade were purchased from Riedel-de Haën (Seelze, Germany). Phosphate buffered saline solution (PBS) was prepared diluting $9.55 \mathrm{~g}$ of PBS DULBECCO from Biochrom AG (Berlin, Germany) in one liter of water. Ochratest Immunoaffinity Columns (IAC) were obtained from Vicam Inc. (Watertown MA, USA). Millipore type I water was used to prepare all of the aqueous solutions and was obtained daily from a Milli-Q water purifying system.

\subsection{Standard solutions}

A stock standard solution of $100 \mathrm{mg} / \mathrm{L}$ was prepared by dissolving $1 \mathrm{mg}$ of OTA in $10 \mathrm{~mL}$ of methanol. It was then stored at $-20{ }^{\circ} \mathrm{C}$. It has been reported that OTA solutions in methanol stored at $-20 C$ are stable over a period of several years [19]. The exact concentration was determined espectrophotometrically at $333 \mathrm{~nm}$ (MW: 403.8; ع: $5500 \mathrm{M}^{-1} \mathrm{~cm}^{-1}$ ) [20]. Working standard solutions and calibration samples were prepared by dilution of stock solution with methanol. Prior to the LC analysis, $200 \mu \mathrm{L}$ of the calibration samples were evaporated at $40 \mathcal{C}$ under nitrogen stream and redissolved in $200 \mu \mathrm{L}$ of mobile phase, in the same way in which the methanol extracts from wine samples were prepared. Quality control of analysis has been carried out by analyzing standard solutions among the wine samples. Moreover, during the years 2002-2005 the laboratory, using the described method, participated in four rounds $(1720,1728,1736,1745)$ for OTA analysis in wine of Food Analysis Performance Assessment Scheme (FAPAS), obtaining satisfactory z scores $(|z| \leq 2)$ in each case.

\subsection{Wine sample preparation and IAC clean-up}

The method was based on that which has been described by Otteneder and Majerus (2000) [11], with some modifications. A $5 \mathrm{~mL}$ aliquot of wine was diluted with $45 \mathrm{~mL}$ of PBS. After shaking, all of the mixture was passed through an IAC column which was preconditioned with $10 \mathrm{~mL}$ of PBS. Afterwards, the IAC was washed with $10 \mathrm{~mL}$ of PBS and $10 \mathrm{~mL}$ of water. Finally, it was dried by passing air with a syringe. OTA was eluted with methanol, 4 times with $1 \mathrm{~mL}$ each at a flow rate of 
20-30 drops/min. The eluate was evaporated to dryness in a water bath at $40 \mathbb{C}$ under nitrogen stream, and the residue was redissolved in $200 \mu \mathrm{L}$ of mobile phase before LC analysis.

\subsection{Apparatus and chromatographic conditions}

The instrument used was an Agilent Technologies 1,100 liquid chromatographic system equipped with a fluorescence detector (model G1321A), controlled by a Chemstation 3D software. The chromatographic conditions were based on the method of Jimenez et al. [21]. Briefly, OTA was analyzed on a $5 \mu \mathrm{m}(25 \mathrm{~cm} \times 0.4 \mathrm{~cm})$ Tracer Extrasil ODS2 column with a Tracer Extrasil ODS-2 precolumn, both from Teknokroma (Barcelona, Spain). The injection volume was $100 \mu \mathrm{L}$ and the flow rate was $1.5 \mathrm{~mL} / \mathrm{min}$, with a mobile phase of 29:29:42 (v/v/v) methanol-acetonitrile-sodium acetate ( $5 \mathrm{mM}$ acidified to $\mathrm{pH} 2.2$ with phosphoric acid). The aqueous phase was filtered through a $0.45 \mu \mathrm{m}$ membrane filter (Millipore, Ibérica S.A. Spain). Chromatography was performed at $40 \mathbb{C}$ and the fluorescence conditions were: $\mathrm{Ex}=225 \mathrm{~nm}, \mathrm{Em}=461 \mathrm{~nm}$. in order to achieve a low limit of detection (LOD) [22]. In these chromatographic conditions, OTA has a retention time of $5.5 \mathrm{~min}$.

\section{Results and Discussion}

\subsection{Method validation}

The selectivity of the method was assured by the use of immunoaffinity purification techniques and a very selective fluorescence detector. Furthermore, some experiments were carried out in order to assess selectivity. When OTA was added to positive samples, an increase of OTA peak area was observed. Moreover, when the proportion of the aqueous component of the mobile phase was increased, the retention time in the OTA peak was delayed, and no other peak, differing from that of OTA, appeared.

Two calibration curves (seven and eight data points, three replicates for each point) were generated by plotting peak areas of OTA versus concentration of calibration samples for two ranges, 0.4 to $1 \mathrm{ng} / \mathrm{mL}$ and 1 to $10 \mathrm{ng} / \mathrm{mL}$ (equivalent to $0.02-0.04$ and $0.04-0.4 \mathrm{ng} / \mathrm{mL}$ in wine). Both calibration curves showed a good linear relationship between peak areas and OTA concentration in both ranges.

Within- and between-day precision and recovery were established by making 27 determinations in spiked wine samples, covering the range of the method (three concentrations of $0.02,0.1$ and $0.4 \mu \mathrm{g} / \mathrm{L} /$ three replicates each one/three different days) and achieving a recovery value of $95.4 \% \pm 5.5 \%$. The limit of detection (LOD) (signal/noise ratio of 3) and of quantification (LOQ) (the lowest concentration assayed that gave good precision and accuracy) were 0.009 and $0.02 \mu \mathrm{g} / \mathrm{L}$, respectively. Moreover, the good results obtained from FAPAS tests demonstrated the suitability of the analytical methodology for OTA determination in wine. With this method, the laboratory was accredited during the years 2002-2005 for OTA determination in wine by the Spanish Accreditation Board (ENAC) under the Standard ISO 17025.

\subsection{Sample analysis}

Figure 2 shows chromatograms obtained after analysis of samples of each type of wine.

The results obtained from the 40 samples analyzed for OTA content are shown in Table 1. 
These results are summarized in Table 2. All of the data has been corrected by recovery (95.4\%) and all of them have been taken into account in the calculation, even those values below LOD, in this case, a value of LOD/2 have been assigned.

All of the samples presented OTA concentration levels below the maximum tolerate level $(2 \mu \mathrm{g} / \mathrm{L})$. Thirty-two (80\%) samples contained detectable OTA amounts, and the overall OTA mean concentration was $0.138 \mu \mathrm{g} / \mathrm{L}$. Taking into account the mean value obtained in this study $(0.138 \mu \mathrm{g} / \mathrm{L})$ and the mean obtained from oloroso wine $(0.319 \mu \mathrm{g} / \mathrm{L})$, and assuming that a consumer weighs $60 \mathrm{~kg}$ with a $50 \mathrm{~mL}$ daily intake of these aperitif wines (consumption of this type of wine is occasional and rarely exceeds $50 \mathrm{~mL} /$ day [1]), the estimated weekly intakes of OTA are 0.8 and $1.9 \mathrm{ng} / \mathrm{kg}$ body weight (bw), respectively, far from the provisional weekly tolerable intake (PTWI) recommended by the Joint FAO/WHO Expert Committee on Food Additives (JECFA) for OTA (100 ng/kg bw) [2].

Figure 2. Chromatograms obtained for each type of wine analyzed: manzanilla (green), fino (pink), amontillado (red) and oloroso (blue).

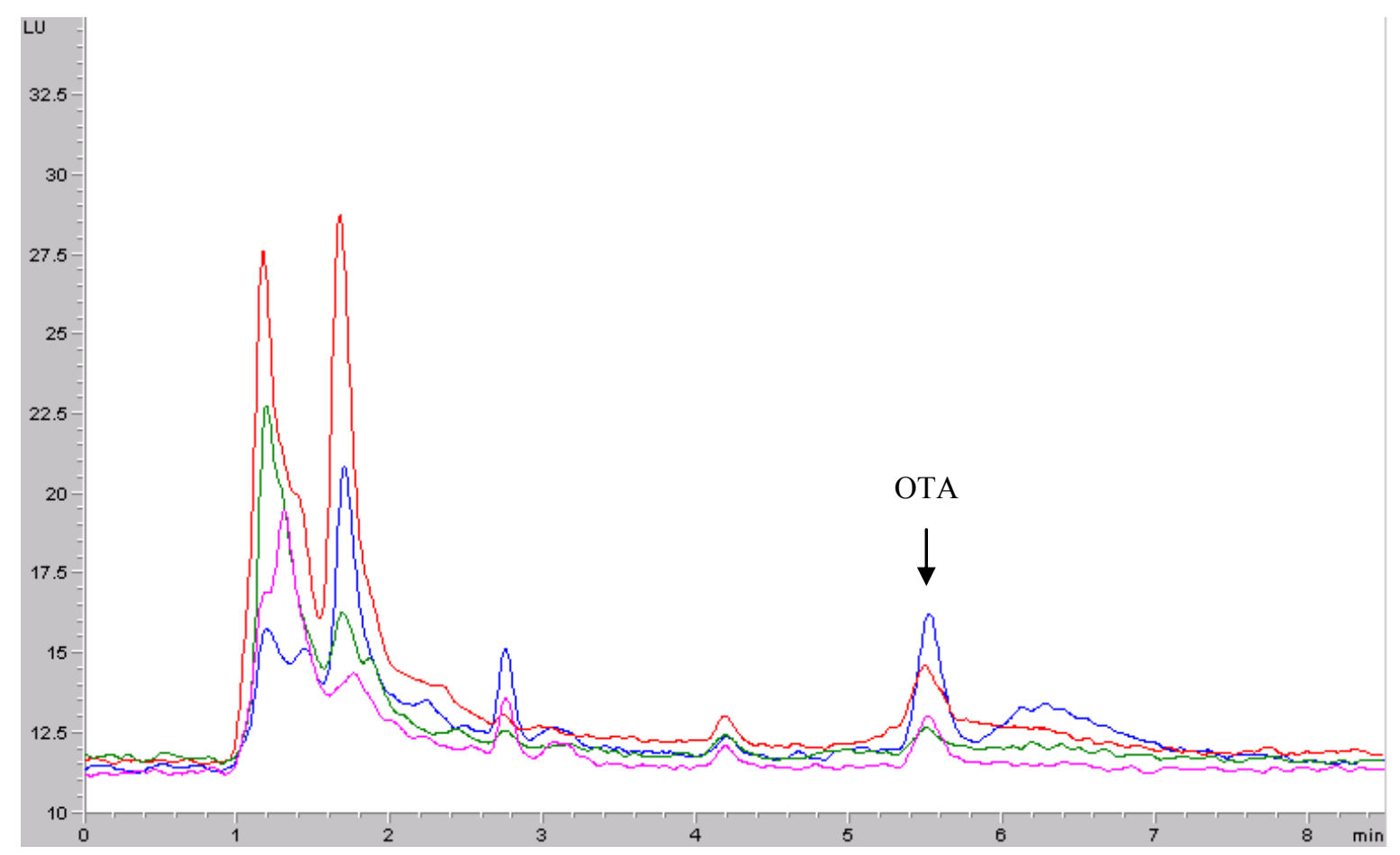

Table 1. OTA levels $(\mu \mathrm{g} / \mathrm{L})$ in wine samples.

\begin{tabular}{lcccccccccc}
\hline Type of wine & \multicolumn{10}{c}{ Sample number } \\
\cline { 2 - 12 } & 1 & 2 & 3 & 4 & 5 & 6 & 7 & 8 & 9 & 10 \\
\hline Manzanilla & 0.053 & 0.039 & 0.058 & 0.086 & 0.048 & 0.059 & 0.067 & $<$ LOD & $<$ LOD & $<$ LOD \\
Fino & 0.092 & 0.110 & 0.087 & 0.084 & 0.047 & $<$ LOD & $<$ LOD & $<$ LOD & $<$ LOD & $<$ LOD \\
Amontillado & 0.413 & 0.132 & 0.177 & 0.161 & 0.151 & 0.185 & 0.048 & 0.049 & 0.042 & 0.085 \\
Oloroso & 0.527 & 0.278 & 0.481 & 0.378 & 0.642 & 0.129 & 0.121 & 0.265 & 0.117 & 0.256 \\
\hline
\end{tabular}

$<$ LOD: below the limit of detection. 
Table 2. Mean and median OTA levels $(\mu \mathrm{g} / \mathrm{L})$ in wine samples, $\%$ of positive samples and range $(\mu \mathrm{g} / \mathrm{L})$.

\begin{tabular}{lcccc}
\hline Type of wine & $\begin{array}{c}\text { Mean value } \\
(\mu \mathrm{g} / \mathrm{L})\end{array}$ & $\begin{array}{c}\text { Median } \\
(\boldsymbol{\mu g} / \mathbf{L})\end{array}$ & $\begin{array}{c}\text { Positive } \\
(\boldsymbol{\%})\end{array}$ & $\begin{array}{c}\text { Range } \\
(\boldsymbol{\mu g} / \mathbf{L})\end{array}$ \\
\hline Manzanilla & 0.042 & 0.051 & 70 & $<\mathrm{LOD}-0.086$ \\
Fino & 0.044 & 0.026 & 50 & $<\mathrm{LOD}-0.110$ \\
Amontillado & 0.144 & 0.142 & 100 & $0.042-0.413$ \\
Oloroso & 0.319 & 0.272 & 100 & $0.117-0.642$ \\
\hline TOTAL & 0.138 & 0.086 & 80 & $<\mathrm{LOD}-0.642$ \\
\hline \multicolumn{5}{l}{$<$ LOD: below the limit of detection. }
\end{tabular}

These types of wines are elaborated from white grapes and they are considered to be white wines. The results obtained in this study can be compared with those reported from different studies carried out on white wines in different countries, in which an OTA level range between $<$ LOD $-1.72 \mu \mathrm{g} / \mathrm{L}$ was obtained. These are summarized in Table 3.

Considering all of the wines studied and the fact that they are white wines, they presented OTA levels similar to those obtained in other studies carried out in Spain [5,25], Greece [8,10] or Italy [13].

Table 3. OTA mean concentration in white wines obtained from different studies.

\begin{tabular}{|c|c|c|c|c|c|}
\hline Origin & $\begin{array}{c}\% \\
\text { Positive } \\
\end{array}$ & $\begin{array}{l}\text { Mean } \\
(\mu \mathrm{g} / \mathrm{L})\end{array}$ & $\begin{array}{c}\text { LOD } \\
(\mu \mathrm{g} / \mathrm{L})\end{array}$ & $\begin{array}{l}\text { Range } \\
(\mu \mathrm{g} / \mathrm{L})\end{array}$ & Reference \\
\hline $\begin{array}{l}\text { European and North } \\
\text { African countries }\end{array}$ & 27 & 0.011 & 0.003 & $<0.003-0.178$ & {$[12]$} \\
\hline \multirow{4}{*}{ Worldwide } & 34 & $0.07 *$ & 0.01 & $<0.01-1.20$ & [14] \\
\hline & 25 & 0.108 & 0.01 & $<0.01-1.36$ & [11] \\
\hline & -- & 0.059 & \multirow{2}{*}{0.05} & $<0.05-0.18$ & \multirow{2}{*}[23]{} \\
\hline & $-{ }^{\mathrm{e}}$ & 0.081 & & $<0.05-0.22$ & \\
\hline European countries & 15 & 0.012 & 0.01 & $<0.01-0.04$ & [11] \\
\hline $\begin{array}{l}\text { Spain and other } \\
\text { European countries }\end{array}$ & 65 & 0.020 & 0.003 & $<0.003-0.267$ & {$[24]$} \\
\hline \multirow{3}{*}{ Spain } & $100^{\mathrm{c}}$ & 0.185 & \multirow{2}{*}{0.05} & $0.154-0.208$ & \multirow{2}{*}[5]{} \\
\hline & $17^{\mathrm{d}}$ & 0.192 & & 0.192 & \\
\hline & 10 & 0.18 & 0.05 & $0.05-1.13$ & {$[25]$} \\
\hline \multirow{2}{*}{ Italy } & $28^{a}$ & 0.045 & \multirow{2}{*}{0.01} & $<0.01-0.06$ & \multirow{2}{*}[13]{} \\
\hline & $100^{\mathrm{b}}$ & 0.535 & & $0.10-0.97$ & \\
\hline Morocco & 100 & 0.073 & $0.01^{\mathrm{f}}$ & $0.028-0.18$ & {$[26]$} \\
\hline \multirow{2}{*}{ Greece } & 55 & 0.250 & 0.05 & $<0.05-1.72$ & [10] \\
\hline & 54 & 0.27 & 0.02 & $<0.02-0.87$ & {$[8]$} \\
\hline South Africa & 100 & 0.17 & 0.01 & $0.04-0.33$ & {$[27]$} \\
\hline Turkey & 85 & 0.108 & 0.006 & $<0.006-0.618$ & {$[28]$} \\
\hline
\end{tabular}

From all of the wines studied in this work, manzanilla and fino wines are considered to be aperitif wines. In the reference literature, Burdaspal and Legarda [24] have studied 47 aperitif wines from six 
different European countries, obtaining an OTA mean concentration of $0.040 \mu \mathrm{g} / \mathrm{L}$. Among them, Spanish wines $(\mathrm{n}=27)$ presented a slightly higher OTA mean value, $0.054 \mu \mathrm{g} / \mathrm{L}$. Zimmerli and Dick [12] studied two Sherry aperitif wines (type not mentioned) and obtained $0.042 \mu \mathrm{g} / \mathrm{L}$ as the OTA mean value, similar to the Burdaspal and Legarda data. These reported results coincide with the levels obtained in the fino and manzanilla wines (OTA mean levels $0.044 \mu \mathrm{g} / \mathrm{L}$ and $0.042 \mu \mathrm{g} / \mathrm{L}$, respectively).

Comparison of the OTA levels in the four different wine groups was carried out using the median non-parametric test. There are significant differences between the groups fino-oloroso $(\mathrm{p}<0.001)$ and manzanilla-oloroso $(\mathrm{p}<0.001)$, while significant differences do not appear between fino and manzanilla wines $(\mathrm{p}=0.656)$, fino and amontillado $(\mathrm{p}=0.179)$, manzanilla and amontillado $(\mathrm{p}=0.179)$ or amontillado and oloroso wines $(\mathrm{p}=0.179)$.

The wines that suffer biological ageing have OTA levels which are significantly lower than oloroso wine, which after suffering an oxidative ageing, have the greatest OTA concentration; and although no significant differences have been observed, it appears that as the biological ageing diminishes, the OTA levels that are obtained tend to be greater. Also, the incidence of OTA in samples is lesser in those wines that suffer a biological ageing (70\% in manzanilla wines and 50\% in fino wines) in contrast with the $100 \%$ of the samples with detectable OTA levels in amontillado and oloroso wines, as can be observed in Figure 3.

Figure 3. Incidence of OTA in samples.

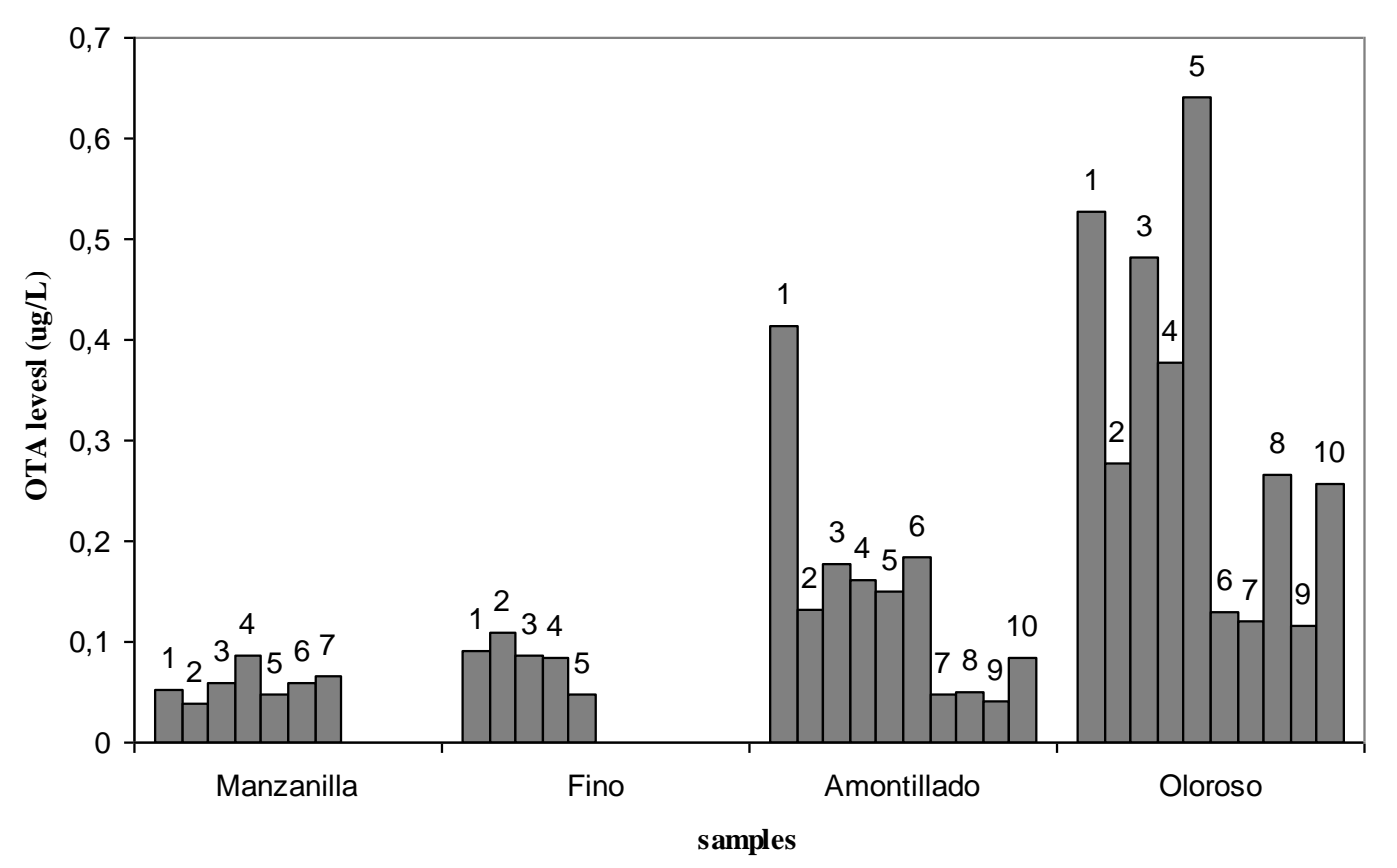

Taking into account these considerations, it could be assumed that there is some type of relationship between the presence of OTA in wine and the presence or absence of the blooming veil, because the difference among these wine groups is the ageing process. Different authors have described that yeast can potentially be used for removing OTA from wine [29]. Several hypotheses could be made: yeast could use OTA as a source of carbon for obtaining energy, thereby reducing the OTA levels in these types of wines [17]. Also, yeast or yeast cell walls could adsorb OTA [30], acting like a 
sponge [18], by different mechanisms such as hydrogen bonding and/or ionic or hydrophobic interactions enhanced by low $\mathrm{pH}$ values (near 3.00) [31]; and the wines under study have an average $\mathrm{pH}$ of 2.9. Thirdly, it is known that there are certain enzymes with the ability to degrade Ochratoxin A, such as lipase A [32] or carboxypeptidase A [33,34]; these enzymes might be present in yeast, thereby decreasing the OTA level in the medium.

\section{Conclusions}

All of the samples of wines under denomination of origin "Jerez-Xérès-sherry and manzanilla Sanlúcar de Barrameda" analyzed presented OTA concentration levels below the maximum tolerate level $(2 \mu \mathrm{g} / \mathrm{L})$, and in general, the mean OTA value does not appear to differ from other data given in the reference literature regarding white wines and aperitif wines. Considering the low levels of mycotoxin found, the risk for consumers due to OTA exposure through the consumption of this type of wines does not appear to be of great concern. However, it is important to keep in mind that wine is only one of the many possible sources of OTA for humans, and a vigilant attitude must be assumed in order to prevent human intake of OTA from food.

It should be pointed out that there is a tendency to obtain greater OTA levels and incidence of OTA in samples as biological ageing diminishes. Moreover, there are significant differences in the OTA levels between wines with exclusive biological ageing and those with oxidative ageing. This study confirms the importance of taking into account the wine-making procedures when survey studies on OTA in wine are carried out. It has been described in the scientific literature that different yeasts can potentially be used for removing OTA from wine. The special procedure used in the preparation of wines of the Denomination of Origin "Jerez-Xérès-Sherry and manzanilla Sanlúcar de Barrameda", in which naturally occurring yeast appears, seems to be a protection against OTA presence.

\section{Acknowledgements}

The authors are grateful to the reviewers, whose comments and suggestions have helped to improve this article. We are grateful to Laura Stokes for reviewing the English version of this manuscript. M. Murillo-Arbizu and S. Amézqueta also wish to thank the Department of Education of the Government of Navarra for the supporting grants.

\section{References}

1. Burdaspal, P.A.; Legarda, T. Occurrence of ochratoxin A in sweet wines produced in Spain and other countries. Food Add. Contam. 2007, 24, 976-986.

2. Joint FAO/WHO Expert Committee on Food Additives (JECFA). Evaluation of Certain Food Additives and Contaminants: Sixty-Eighth Report of the Joint FAO/WHO Expert Committee on Food Additives; Technical Report Series No.947; World Health Organization: Geneva, Switzerland, 2007.

3. Pfohl-Leszkowicz, A. Ochratoxin A and aristolochic acid in the nephropathies and associated urothelial tract tumours development. Arh. Hig. Rada Toksikol. 2009, 60, 465-483. 
4. IARC. Monographs on Evaluation of Carcinogenic Risks to Humans. Some Naturally Occurring Substances: Food Items and Constituents, Heterocyclic Aromatic Amines and Mycotoxins; International Agency for Research on Cancer: Lyon, France, 1993; Volume 56, pp. 489-521.

5. Lopez de Cerain, A.; Gonzalez-Peñas, E.; Jimenez, A.M.; Bello, J. Contribution to the study of ochratoxin A in Spanish wines. Food Add. Contam. 2002, 19, 1058-1064.

6. Pfohl-Leszkowicz, A.; Manderville, R. Review on Ochratoxin A: An overview on toxicity and carcinogenicity in animals and humans. Mol. Nutr. Food Res. 2007, 51, 61-99.

7. European Commission. Commission Regulation No. 123/2005 of 26 January 2005 amending regulation No. 466/2001 as regards ochratoxin A. Off. J. Eur. Union 2005, L25, 3-5.

8. Soufleros, E.H.; Tricard, C.; Bouloumpasi, E.C. Occurrence of ochratoxin A in Greek wines. J. Sci. Food Agric. 2003, 83, 173-179.

9. Zimmerli, B.; Dick, R. Determination of ochratoxin A at the ppt level in human blood, serum, milk and some foodstuffs by high-performance liquid chromatography with enhanced fluorescence detection and immunoaffinity column cleanup" methodology and Swiss data. J. Chromatogr. B 1995, 666, 85-99.

10. Stefanaki, I.; Foufa, E.; Tsatsou-Dritsa, A.; Dais, P. Ochratoxin A concentrations in Greek domestic wines and dried vine fruits. Food Add. Contam. 2003, 20, 74-83.

11. Otteneder, H.; Majerus, P. Occurrence of ochratoxin A (OTA) in wines: Influence of the type of wine and its geographical origin. Food Add. Contam. 2000, 17, 793-798.

12. Zimmerli, B.; Dick, R. Ochratoxin A in table wine and grape-juice: Occurrence and risk assessment. Food Add. Contam. 1996, 13, 655-668.

13. Visconti, A.; Pascale, M.; Centonze, G. Determination of Ochratoxin A in wine by means of immunoaffinity column clean-up and high-performance liquid chromatography. J. Chromatog. A 1999, 864, 89-101.

14. Majerus, P.; Otteneder, H. Detection and occurrence of ochratoxin A in wine and grapejuice. Deut. Lebesnm. Rundsch. 1996, 92, 388-390.

15. Brera, C.; Debegnach, F.; Minardi, V.; Prantera, E.; Pannunzi, E.; Faleo, S.; de Santis, B.; Miraglia, M. Ochratoxin A contamination in Italian wine samples and evaluation of the exposure in the Italian population. J. Agric. Food Chem. 2008, 56, 10611-10618.

16. Altiokka, G.; Can, N.O.; Atkosar, Z.; Aboul-Enein, H.Y. Determination of ochratoxin A in Turkish wines. J. Food Drug Anal. 2009, 17, 467-473.

17. Valero, A.; Marin, S.; Ramos, A.J.; Sanchis, V. Survey: Ochratoxin A in European special wines. Food Chem. 2008, 108, 593-599.

18. Meca, G.; Blaiotta, G.; Ritieni, A. Reduction of ochratoxin A during the fermentation of Italian red wine Moscato. Food Contr. 2010, 21, 579-583.

19. Valenta, H. Chromatographic methods for the determination of Ochratoxin A in animal and human tissues and fluids. J. Chromatog. A 1998, 815, 75-92.

20. Pohland, A.E.; Schüller, P.L.; Steyn, P.S.; van Egmond, H. Physicochemical data for selected mycotoxins. Pure Appl. Chem. 1982, 54, 2219-2284.

21. Jimenez, A.M.; Lopez de Cerain, A.; Gonzalez-Peñas, E.; Bello, J. A high-performance liquid-chromatographic method for the determination of ochratoxin A in human plasma. Chromatographia 1999, 50, 457-460. 
22. Amézqueta, S.; González-Peñas, E.; Murillo, M.; López de Cerain, A. Validation of a high-performance liquid chromatography analytical method for ochratoxin A quantification in cocoa beans. Food Add. Contam. 2004, 21, 1096-1106.

23. Chiodini, A.M.; Scherpenisse, P.; Bergwerff, A.A. Ochratoxin A contents in Wine: Comparison of organically and conventionally produced products. J. Agri. Food Chem. 2006, 54, 7399-7404.

24. Burdaspal, P.A.; Legarda, T.M. Ochratoxin A in wines and grape products originated from Spain and other European countries. Alimentaria 1999, 36, 107-113.

25. Belli, N.; Marin, S.; Duaigues, A.; Ramos, A.J.; Sanchis, V. Ochratoxin A in wines, musts and grape juices from Spain. J. Sci. Food Agric. 2004, 84, 541-546.

26. Filali, A.; Ouammi, L.; Betbeder, A.M.; Baudrimont, I.; Soulaymani, R.; Benayada, A.; Creppy, E.E. Ochratoxin A in beverages from Morocco: A preliminary survey. Food Add. Contam. 2001, $18,565-568$.

27. Shephard, G.S.; Fabiani, A.; Stockenstrom, S.; Mshicileli, N.; Sewram, V. Quantitation of Ochratoxin A in South African Wines. J. Agric. Food Chem. 2003, 51, 1102-1106.

28. Var, I.; Kabak, B. Occurrence of ochratoxin A in Turkish wines. Microchem. J. 2007, 86, 241-247.

29. Var, I.; Erginkaya, Z.; Kabak, B. Reduction of ochratoxin A levels in white wine by yeast treatments. J. Inst. Brew. 2009, 115, 30-34.

30. Bizaj, E.; Mavri, J.; Cus, F.; Raspor, A. Removal of ochratoxin A in saccharomyces cerevisiae liquid cultures. S. Afr. J. Eonol. Vitic. 2009, 30, 151-155.

31. Huwig, A.; Freimund, S.; Kappeli, O.; Dutler, H. Mycotoxin detoxification of animal feed by different adsorbents. Toxicol. Lett. 2001, 122, 179-188.

32. Stander, M.A.; Bornscheuer, U.T.; Henke, E.; Steyn, P.S. Screening of commercial hydrolases for the degradation of ochratoxin A. J. Agric. Food Chem. 2000, 48, 5736-5739.

33. Deberghes, P.; Deffieux, G.; Gharbi, A.; Betbeder, A.M.; Boisard, F.; Blanc, R.; Delaby, J.F.; Creppy, E.E. Detoxification de l'ochratoxine A par des moyens physiques, chimiques et enzymatiques. Hum. Ochratoxicosis Pathol. 1993, 231, 75-82.

34. Karlovsky, P. Biological detoxification of fungal toxins and its use in plant breeding, feed and food production. Nat. Toxins 1999, 7, 1-23.

(C) 2010 by the authors; licensee MDPI, Basel, Switzerland. This article is an Open Access article distributed under the terms and conditions of the Creative Commons Attribution license (http://creativecommons.org/licenses/by/3.0/). 